\title{
Instead of a Conclusion: Some Other Problems with Children's Rights
}

\author{
Zdenko Kodelja, Educational Research Institute, Slovenia
}

\begin{abstract}
A $s$ evident in academic discussions, including in this thematic issue, children's rights are usually understood today as moral rights and also as internationally recognised legal norms that all countries should respect and protect. However, this does not mean that children's rights are no longer unambiguous and uncontroversial. Just the opposite, several problems concerning children's rights remain unresolved. In this paper, I shall discuss - very shortly - only three of them: the relationship between human and children's rights; the controversy over children's liberty rights; and the antinomy of rights, that is, the opposition between the right of the child to freedom of religion and the right of parents to educate their children in conformity with their own religious convictions.
\end{abstract}

\section{Human and children's rights}

The first problem is interesting for the following reason: If, according to the Universal Declaration of Human Rights adopted by the United Nations in 1948, "everyone is entitled to all the rights and freedoms set forth in this Declaration" (Art. 2), then children must also possess them. Therefore, there is either no need to indicate and guarantee these rights once again in the Convention on the Rights of the Child (adopted by the United Nations in 1989) because it either paradoxically gives children something that they already had, or the word "everyone" in the Declaration does not refer to children, and for this reason children's rights were provided in the Convention. But this would mean that children are not (yet) human beings and yet that is precisely why they could not have all the rights given in 
the Declaration to every human being, "without distinction of any kind, such as race, colour, sex, language, religion, political or other opinion, national or social origin, property, birth or other status" (ibid.). This conclusion seems unacceptable for members of the child's liberation movement, who defend children's rights as derived from human rights based on the following syllogism:

(I). All children are human beings.

(2). All human beings have all human rights.

(3). Therefore: all children have all human rights. (Apostel, 1989, p. 49)

Although this syllogism (called Barbara in the context of Aristotelian logic) is valid, some believe the conclusion is false because the first premise is not true. They agree that children are human beings, but for them children are human beings only "in those respects in which they do not differ from adult human beings in general" (ibid., p. 5I). Since children are children in virtue of "those respects which they differ from human beings that are not children", the conclusion is not derivable. According to them, it is not derivable for the same reason as it is not derivable in the following case where based on the premises that all birds fly, and that the ostrich is a bird, we cannot conclude that the ostrich flies (ibid.).

The children's rights stated in the Convention on the Rights of the Child are usually interpreted as human rights which protect the child as a human being. However, this Convention "gives the rights to children only and in so far as they are children" (Archard, 2004, p. 60). It seems that it does so because the child - as is written in the Preamble: "by reason of his physical and mental immaturity, needs special safeguards and care, including appropriate legal protection, before as well as after birth". Hence, it is not surprising that the Convention provides them with "protection rights", which protect children from violent, abusive, cruel or exploitative treatment; and "welfare rights", which "protect important interests (such as health, bodily integrity, and privacy)" (ibid.). What is surprising is that it gives them liberty rights as well.

\section{Liberty rights}

The second problem may be expressed in the question of whether children can or should have liberty rights, that is, the rights to freedom of speech, religion, association, and so on. These rights present a serious problem because they presuppose the autonomy and responsibility of the subjects of rights. Since children - at least when they are very young - are neither autonomous nor responsible, it is absurd, as say some philosophers (cf. I08 
Renaut, 2003), to give them liberty rights. In addition, they are persuaded that liberty rights should not be given to children also for another reason: the fact that liberty rights are given to them by the Convention on the Rights of the Child means that children are (or that they should be) treated as autonomous and responsible persons; that is to say, as adults. As a result, children would lose exactly those personal characteristics which make them different from adults. But if children do not differ from adults in this regard, there is no longer any justifiable reason to treat them as human beings who, according to the same Convention, by reason of their physical and mental immaturity, need special care, protection and assistance. Children would therefore lose the right to be what they are, namely, to be different from adults.

The problem of liberty rights relates to the Convention on the Rights of the Child and not to two earlier international documents, namely, the Geneva Declaration on the Rights of the Child (adopted in 1924) and the United Nations Declaration on the Rights of the Child (adopted in 1959), in which liberty rights are not mentioned. The liberty rights guaranteed by the Convention include the right of the child to freedom of religion. Not only is this right problematic because it belongs to the liberty rights, but also because it is in opposition to the right of parents to educate their children in line with their own religious convictions.

\section{Antinomy of rights}

In this case, there is an antinomy of rights or, in other words, a contradiction or conflict between rights. Parents have, under the Universal Declaration of Human Rights, the same right to freedom of thought, conscience and religion ${ }^{\mathrm{I}}$ as their children have as provided by the Convention on the Rights of the Child. ${ }^{2}$ As both children and parents have the same right, when education in accordance with this right is in question, it is obvious that they can both claim it only if there are no differences between them. If, however, differences exist, either the child or the parents can claim it. If we also consider other international documents on human rights, we see that until the Convention on the Rights of the Child was adopted in 1989 it was clear that parents held the right "to ensure their children the religious and moral education in accordance with

"Everyone has the right to freedom of thought, conscience and religion; this right includes freedom to change his religion or belief, and freedom, either alone or in community with others and in public or private, to manifest his religion or belief in teaching, practice, worship and observance" (Universal Declaration of Human Rights, 1948, Article 18).

2 "States Parties shall respect the right of the child to freedom of thought, conscience and religion" (Convention on the Rights of the Child, 1989, Article I4.I). 
their own religious and philosophical convictions", ${ }^{3}$ although this right was sometimes even mentioned as a right of the child. This is especially evident in The Declaration on Eliminating all Forms of Intolerance and Discrimination Based on Religion or Belief, which provides that every child has "the right to education, regarding religion or belief, in accordance with the wishes of his parents". ${ }^{4}$ If it were the right of the child, it should then be their right to be educated regarding religion or belief in line with their wishes and not those of their parents. In my opinion, in this context, the child's right is nothing more than a synonym for the parents' right to determine the child's religious education.

In this context, parents are treated as people who have the same religious or philosophical convictions. Yet should the parents of a child hold different religious or philosophical convictions, legal and practical problems with implementation of this right of the parents can arise. Of course, having different convictions is not yet a sufficient condition for the antinomy of rights. What is lacking is an intention or the will of each parent to use this right. It is only when the father wants to educate his children according to his convictions and the mother to hers that the problem is unsolvable. However, despite this undiscriminating formulation of this particular parents' right, there is no doubt that parents, under the mentioned international Conventions and Declarations, possess the right to educate their children consistently with their religious convictions.

Nonetheless, it seems that the Convention on the Rights of the Child has taken a significant step toward a different interpretation of the parents' rights to education regarding their child's religion. According to this Convention, the States shall respect the rights and duties of the parents "to provide direction to the child in the exercise of his or her right in a manner consistent with the evolving capacities of the child". The emphasis is now on the child's right to freedom of religion, which their parents must respect. Yet, the key question is: what does "the child's right to freedom of religion" really mean? The right includes the child's freedom to manifest his or her religion or beliefs. ${ }^{6}$ But does this right also include a child's "freedom to have or to adopt a religion or whatsoever belief of his

"In the exercise of any function which it assumes in relation to education and to teaching, the State shall respect the right of parents to ensure such education and teaching in conformity with their own religious and philosophical convictions" (European Convention on Human Rights, 1950, Protocol I to the Convention, Article 2); Cf. The International Convention on Economic, Social and Cultural Rights, 1966, Article 13.

4 The Declaration on Eliminating all Forms of Intolerance and Discrimination Based on Religion or Belief, 1960, Article 5.

5 Convention on the Rights of the Child, Article I4.2.

6 This "freedom to manifest one's religion or beliefs may be subject only to such limitations as are prescribed by law and are necessary to protect public safety, order, health or morals, 
own choice", as was anticipated in the draft version of the Convention? If so, then why did this explicit definition disappear from the final version? If not, this right loses its raison d'être. Still, although we do not know answers to these questions, it is clear that parents' right to provide direction to their child in the exercise of his or her right to freedom of religion is not identical to the parents' right to ensure the religious and moral education of the child in conformity with the parents' religious or philosophical convictions. Otherwise, the child's right to freedom of religion would be violated.

On one hand, this right of the child is limited by the parents' right to direct children in exercise of this right. This limitation probably presupposes that children are unable to exercise the right to freedom of religion for themselves because they lack reason and therefore cannot act freely. That is why, as John Locke said, parents have the right to direct them to the point when they are able to make rational, autonomous decisions for themselves. In this context, we can then say that the aim of such parents' educational guidance should be the child's self-determination of their religion.

On the other hand, this right of parents is also limited. As we have seen, parents ought to direct their children "in a manner consistent with the evolving capacities of the child". This means parents' influence on the child should be decreased in proportion to the increasing capacities of the child. Although the Convention on the Rights of the Child does not define the capacities of children, it seems plausible, considering Locke's and many other contemporary arguments about children's rights, to believe that these capacities are essentially related to their rationality and consequentially, in the moment the child becomes a rational being, the parents' right to direct him/her comes to an end.

Therefore, it seems obvious that parents would no longer be permitted to make decisions only on the grounds of their own religious or philosophical viewpoints. Especially in the case of children older than $\mathrm{I} 2$ or I3 years who are, in principle, recognised as having the ability to make rationale choices. If parents, despite this, make decisions without considering the child's opinion and wishes, the child's right to freedom of religion is violated. Even the child's support for such a parental decision which emerges at some future date does not justify it because it itself might be the product of the process of the parents' intervention. Bob Franklin gives us the following example: "a child who is forced by parents to attend church, pray and read the Bible may indeed concur, if asked at some future date, that they now consent to the earlier parental wish" (Franklin,

or the fundamental rights and freedoms of others" (Convention on the Rights of the Child, Article 14.3). 
1986, p. 35). Yet, such justifiability of the parents' intervention is problematic considering John Rawls' warning: “imagine two persons in full possession of their reason and who will affirm different religious or philosophical beliefs, and suppose that there is some psychological process that will convert each to the other's view, despite the fact that the process is imposed upon them against their wishes. In due course, let us suppose, both will come to accept conscientiously their new beliefs. We are still not permitted to submit them to this treatment" (Rawls, 1972, p. 249).

Therefore, following ratification of the Convention on the Rights of the Child, the question arises as to how the State, which shall equally respect the rights of both parents and children, should ensure the conditions for implementation of the child's right without simultaneously violating the same right of their parents.

\section{References}

Apostel, L. (1989) Children's Rights and Needs and/or Human Rights and Needs. Open Problems and Personal Convictions. In Verhellen, E., and Spiesschaert, F. (eds.). Ombudswork for Children, pp. 47-85. Leuven: Acco.

Archard, D. (2004) Children. Rights and Childhood. London: Routledge.

Convention on the Rights of the Child (1989) Retrieved from: https://www. ohchr.org/en/professionalinterest/pages/crc.aspx (20 September 2020).

Declaration on Eliminating all Forms of Intolerance and Discrimination Based on Religion or Belief (1960) Retrieved from: https://www. ohchr.org/EN/ProfessionalInterest/Pages/ReligionOrBelief.aspx (20 September 2020).

European Convention on Human Rights (1950) Retrieved from: https:// www.echr.coe.int/documents/convention_eng.pdf (20 September 2020).

Franklin, B. (1986) Children's Political Rights. In Franklin, B. (ed.). The Rights of Children, pp. 24-53. New York: Basil Blackwell.

International Convention on Economic, Social and Cultural Rights (1966) Retrieved from: https:/www.ohchr.org/en/professionalinterest/pages/ cescr.aspx (20 September 2020).

Rawls, J. (1972) A Theory of Justice. Oxford: Oxford University Press.

Renaut, A. (2003) La libération des enfants. Contribution philosophique à une histoire de l'enfance. Paris: Hachette.

Universal Declaration of Human Rights (1948) Retrieved from: https:// www.un.org/en/universal-declaration-human-rights/ (2o September 2020). 